REVIEW

\title{
Anatomy of coronary disease in diabetic patients: an explanation for poorer outcomes after percutaneous coronary intervention and potential target for intervention
}

\author{
K P Morgan, A Kapur, K J Beatt
}

Heart 2004;90:732-738. doi: 10.1136/hrt.2003.021014

There are over 1.3 million known diabetic patients in the UK and a similar number who have the disease undiagnosed. Over $90 \%$ have non-insulin dependent diabetes mellitus usually characterised by insulin resistance and adult onset. Over half of all diabetic patients die of coronary disease and account for over a fifth of percutaneous coronary intervention $(\mathrm{PCl})$ revascularisation procedures. Despite recent therapeutic advances such as new antiplatelet treatments and drug eluting stents, outcomes for diabetic patients after $\mathrm{PCl}$ are still significantly worse than for non-diabetic patients. This article summarises what is known about the pattern and severity of diabetic coronary disease, what mechanisms are responsible for these differences, and whether this information can help explain the poorer prognosis for these patients after $\mathrm{PCl}$ and form the basis of interventions to improve outcome.

See end of article for authors' affiliations

Correspondence to:

Correspondence
Dr Kevin J Beatt, Department of Cardiology, National Heart and Lung Institute, Hammersmith Campus, London W12 ONN, UK; k.beatt@ imperial.ac.uk

Accepted

18 December 2003
$\mathrm{T}$ here are over 1.3 million known diabetic patients in the UK and a similar number with the disease undiagnosed. Over $90 \%$ have non-insulin dependent diabetes mellitus (NIDDM), usually characterised by insulin resistance and adult onset. Over half of all diabetic patients die of coronary artery disease (CAD) and account for over a fifth of percutaneous coronary revascularisation procedures. Despite recent therapeutic advances such as new antiplatelet treatments and drug eluting stents, outcomes for diabetic patients after percutaneous coronary intervention (PCI) are still significantly worse than for non-diabetic patients. This article summarises what is known about the pattern and severity of diabetic CAD, what mechanisms are responsible for these differences, and whether this information can help explain the poorer prognosis for these patients after PCI and form thebasis of interventions to improve outcome.

The introduction of intracoronary stenting in the late 1980s greatly changed the practice of angioplasty by reducing restenosis rates and improving outcome. ${ }^{12}$ Stenting was shown to be especially beneficial for diabetic patients. ${ }^{3}$

The importance of platelet inhibition was known even before this. More recently, advances including the synergistic use of the oral thienopyridine clopidogrel along with aspirin and periprocedural infusions of glycoprotein IIb/IIIa inhibitors have provided further benefit. Pooled analysis of the three abciximab trials (EPIC (evaluation of C7E3 Fab in the prevention of ischemic complications), EPILOG (evaluation of PTCA to improve long-term outcome with abciximab GP IIb/IIIa blockade), and EPISTENT (evaluation of platelet IIb/IIIa inhibitor for stenting)) shows that abciximab decreased the one year mortality in diabetic patients from $4.5 \%$ to $2.5 \%$ and in non-diabetic patients from $2.6 \%$ to $1.9 \%{ }^{4}$

Studies examining optimal PCI with drug eluting stents and glycoprotein IIb/IIIa inhibitors are encouraging. Increased benefit was seen again in the diabetic subgroup with relative rates of target lesion revascularisation reduced by about $70 \% .^{56}$

The evolution in PCI technology has led to a reassessment of its role in the revascularisation of diabetic patients with multivessel disease. Large scale studies have shown that for patients with multivessel disease, although restenosis rates are higher among patients undergoing PCI than among those undergoing coronary artery bypass grafting (CABG), mortality rates are equal. ${ }^{7}$ However, diabetic subgroup analysis has led to the conclusion that PCI is inferior to CABG in these patients. ${ }^{89}$ It is difficult to extrapolate this conclusion to present day practice, as many of these trials were in the pre-stent era and all examined the diabetic group retrospectively. The CARDia (coronary artery revascularisation in diabetics) trial currently recruiting will answer whether optimal PCI is not inferior to up to date CABG in diabetic patients.

\section{PATHOPHYSIOLOGY OF DIABETES MELLITUS}

Insulin resistance is the first detectable abnormality found among patients who develop NIDDM

Abbreviations: BARI 2D, bypass angioplasty revascularisation investigation; $C A B G$, coronary artery bypass grafting; $C A D$, coronary artery disease; CARDia, coronary artery revascularisation in diabetics; CASS, coronary artery surgery study; DM, diabetes mellitus; EPIC, evaluation of C7E3 Fab in the prevention of ischemic complications; EPILOG, evaluation of PTCA to improve long-term outcome with abciximab GP Ilb/llla blockade; EPISTENT, evaluation of platelet $\mathrm{llb} / \mathrm{llll}$ a inhibitor for stenting; IDDM, insulin dependent diabetes mellitus; MACE, major adverse cardiac events; NIDDM, noninsulin dependent diabetes mellitus; $\mathrm{PCl}$, percutaneous coronary intervention; UKPDS, United Kingdom prospective diabetes study; VCAM-1, vascular cell adhesion molecule 1 
and pre-dates the onset of overt hyperglycaemia by several years. It is implicated in the pathogenesis of a number of disorders that all have in common the same final effect of hyperinsulinaemia, low grade inflammation, and metabolic dysfunction. These disorders are collectively called the insulin resistance or metabolic syndrome and include abdominal obesity, increased triglyceride concentrations, decreased high density lipoprotein concentrations, raised blood pressure, and increased plasma glucose concentration.

As insulin resistance increases and pancreatic $\beta$ cell function declines, NIDDM ensues.

\section{PATHOPHYSIOLOGY OF CAD IN NIDDM}

An association between diabetes mellitus (DM) and angina pectoris was first described in 1883 and shortly after it was hypothesised that the association was due to atherosclerosis. ${ }^{10}{ }^{11}$ Much progress has been made in understanding the mechanisms underlying these observations (fig 1).

\section{Insulin resistance}

Hyperinsulinaemia, the biochemical hallmark of insulin resistance, is independently associated with an increased incidence of CAD. ${ }^{12}$ Additionally, the insulin resistance syndrome is associated with increased coronary risk. ${ }^{13-15}$ Insulin receptors are found on endothelial cells of both large and small blood vessels. They are thought to mediate glucose homeostasis and control of vascular tone. Insulin has been shown to effect the secretion of the potent vasoconstrictors vascular endothelial growth factor and endothelin 1. Insulin also acts as a vasodilator in skeletal muscle through secretion of endothelial nitric oxide synthase. Interestingly this effect is impaired in insulin resistance.

\section{Endothelial dysfunction}

Endothelial dysfunction is defined as an imbalance where vasoconstriction outweighs the vasodilatory properties of the endothelium. Impaired vasodilatation is associated with increased cardiovascular risk and is apparent in patients with insulin resistance even before the development of overt hyperglycaemia.

\section{Hyperglycaemia}

Prolonged hyperglycaemia results in non-enzymatic glycosylation of proteins and lipids, oxidative stress, and protein kinase $\mathrm{C}$ activation, which is implicated in the development of coronary atherosclerosis. These pathways are complex and interlinked and their end effects are often irreversible. ${ }^{16}$

\section{Dyslipidaemia}

Insulin resistance and NIDDM are associated with decreased high density lipoprotein and increased synthesis of the highly atherogenic low density lipoprotein particle. In the presence of hyperglycaemia this lipoprotein becomes glycosylated and is poorly recognised by the low density lipoprotein receptor. It is scavenged by tissue macrophages creating the foam cell, a constituent of the atherosclerotic plaque.

\section{Inflammation}

Vascular inflammation is important in the development of atherosclerosis and in determining plaque stability. ${ }^{17}$ Insulin resistance and DM are associated with upregulation of systemic acute phase reactants including $\mathrm{C}$ reactive protein. $^{18}{ }^{19}$ Increased serum $C$ reactive protein concentration is associated with adverse cardiac outcomes. ${ }^{2021}$ Circulating leucocytes are recruited at atherosclerotic sites by adhesion molecules such as vascular cell adhesion molecule 1 (VCAM-1). During endothelial activation the soluble form of VCAM-1 is shed into the circulation and is found in higher concentrations in patients with NIDDM than in non-diabetic controls. Concentrations of soluble VCAM-1 are also independently associated with increased coronary risk in patients with NIDDM. ${ }^{22}$

\section{Prothrombotic state}

Increased concentrations of von Willebrand factor, factor VII, factor VIII, and plasminogen activator inhibitor type 1 are all

\section{Hyperglycaemia}

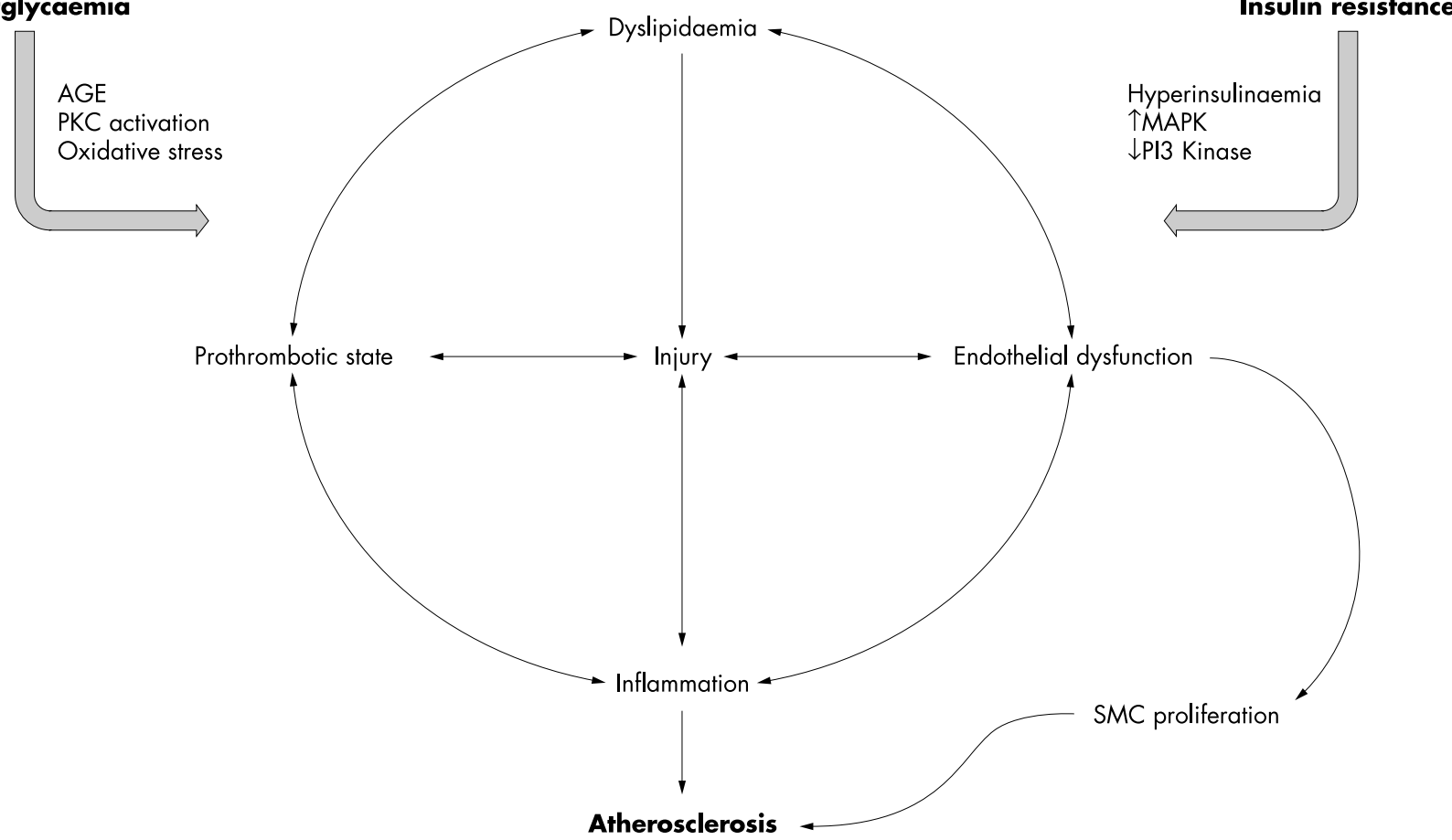

Figure 1 Insulin resistance and hyperglycaemia drive the atherosclerotic process. AGE, advanced glycation end products; MAPK, mitogen activated protein kinase; PI3, phosphatidylinositol 3 kinase; PKC, protein kinase C; SMC, smooth muscle cell. 
associated with the diabetic state resulting in potentiation of the coagulation cascade and platelet activation.

\section{WHAT MECHANISMS UNDERLIE THE POORER OUTCOMES AFTER PCI?}

The higher rates of repeat revascularisation and mortality after PCI in diabetic patients are mediated by two processes: restenosis and disease progression. These processes are effected in part by the metabolic dysregulation resulting from chronic hyperglycaemia and insulin resistance.

\section{Disease progression}

DM is associated with platelet and endothelial dysfunction resulting in accelerated atherosclerosis and plaque instability. Atheromatous plaques from diabetic patients removed by coronary atherectomy have greater lipid deposits and numbers of phagocytes. ${ }^{23}$ Diabetic patients presenting with an acute coronary syndrome are more likely to have a larger culprit lesion with associated plaque ulceration and intracoronary thrombus. ${ }^{24}$ Endothelial dysfunction is thought to induce negative arterial remodelling in response to atherosclerosis resulting in a decrease in luminal size.

\section{Restenosis after $\mathrm{PCl}$}

Restenosis is caused by neointimal proliferation by vascular smooth muscle cells as a consequence of endothelial damage after balloon inflation and stent placement. Rates of restenosis and mortality are significantly higher among diabetic patients after PCI. ${ }^{25}$

A recent study examining the angiographic characteristics of diabetic patients requiring repeat revascularisation after multivessel PCI found that, of 18 patients who required repeat revascularisation, nine had evidence of significant disease progression in addition to restenosis and three had evidence of disease progression only. Disease progression contributed to over half of the requirement for further revascularisation procedures. ${ }^{26}$

Studies at the molecular, cellular, and clinical levels all agree that diabetic CAD is more aggressive. Understanding these differences and devising treatment interventions based on these observations are key to improving outcomes after PCI in these patients. Do diabetic patients have particular patterns and severity of disease, which account for their poorer prognosis?

\section{PATTERN OF CAD IN DIABETIC PATIENTS Vessel calibre}

Coronary artery calibre is associated with body mass index and tends to be smaller in women. A small study has also reported significantly smaller sized vessels in 13 diabetic patients with normal angiograms than in controls. ${ }^{27}$ Small vessel size is strongly associated with increased risk of inhospital mortality after $\mathrm{CABG} .^{28}$ Smaller target vessel size is also associated with increased risk of restenosis and need for repeat revascularisation after PCI. ${ }^{29}$ It has been argued that this association explains the increased procedural risk among women and smaller patients after adjustment for sex and other clinical parameters.

\section{Vessel involvement}

The number of diseased vessels predicts future cardiac morbidity and mortality. ${ }^{30}$ There is convincing evidence that diabetic patients have a higher incidence of multivessel disease. ${ }^{31-35}$

\section{Location of lesions}

Proximal segments and ostial disease are prognostically significant and are associated with a lower risk of procedural success and a higher rate of major adverse cardiac events (MACE) after PCI. It is unknown whether these lesions are found more commonly in patients with NIDDM. A higher incidence of left main stem disease is associated with NIDDM. ${ }^{36}$

\section{Type of lesions}

Lesions at the bifurcation of two epicardial vessels present a technical challenge to the interventionist and are associated with a higher incidence of MACE. It is unclear whether these lesions are found more commonly in diabetic patients. Similarly, total occlusions are associated with worse procedural outcome and higher rates of MACE. Some studies have observed an increase in the number of total occlusions in diabetic patients.

\section{Collateral circulation}

The development of a collateral coronary circulation is thought to be an important cardioprotective mechanism mediated by the endothelium in response to the development of significant myocardial ischaemia. Collateral vessel development has been shown to be impaired in DM. ${ }^{37}$ However, it is unknown what effects this has on outcomes or whether there is any relation with markers of inflammation and endothelial activation.

\section{Coronary artery calcification}

The onset of coronary atherosclerosis is paralleled by the development of calcification. Both insulin resistance and NIDDM are associated with increased coronary artery calcification scores as determined by electron beam computed tomography. ${ }^{38} 39$ The value of quantifying coronary artery calcification to stratify risk is controversial. However, PCI involving a calcified lesion is associated with a reduced risk of procedural success and increased risk of MACE after PCI.

\section{SEVERITY OF CAD IN DIABETIC PATIENTS}

Few would argue that diabetic patients tend to have a more severe and diffuse pattern of CAD, but how well has this been characterised and can we learn anything from this?

Disease severity can be usefully defined in terms of the extent of atheroma affecting the coronary tree and the number of significant stenoses.

Multivariate analysis of over 15000 patients in CASS (coronary artery surgery study) showed a modest independent association between the presence of DM and increased severity of $\mathrm{CAD} .{ }^{40}$ Most postmortem and angiographic studies agree that the severity of CAD is increased in patients with NIDDM. ${ }^{31} 323435$ 41-48 However, some studies have found no difference. ${ }^{36} 4950$ Table 1 summarises these studies.

These varying conclusions may be the result of poor study design, low numbers of patients, and technical limitations in quantifying disease severity. Quantitative coronary angiography has been validated as an accurate means of measuring coronary severity. ${ }^{51}$ Only two studies have used quantitative coronary angiography to examine CAD severity in patients with NIDDM. ${ }^{48}{ }^{52}$ Both found increased CAD severity in the diabetic groups.

IDDM has also been shown to be associated with increased disease severity. ${ }^{5354}$

Stable angina symptoms are usually caused by the development of atherosclerotic plaque obstructing more than $70 \%$ of the lumen of the coronary vessel and are visualised easily at the time of coronary angiography. Stenosis severity is associated with increasing coronary risk. ${ }^{30}$ However, plaques of only mild to moderate severity are more frequently associated with acute coronary syndromes simply because they occur much more often. ${ }^{46}{ }^{55}$ This suggests that extensive and diffuse disease may be of more prognostic significance than less extensive disease with more severe stenoses. The majority of evidence supports the assertion that diabetic patients have a greater number of lesions causing significant 
Table 1 Summary of trials characterising the severity of coronary artery disease (CAD)

\begin{tabular}{|c|c|c|c|c|c|}
\hline $\begin{array}{l}\text { Author and } \\
\text { date }\end{array}$ & Study type & Inclusion criteria & $\begin{array}{l}\text { Number of } \\
\text { diabetic } \\
\text { patients }\end{array}$ & Methods for assessing severity & Findings in diabetic group \\
\hline \multicolumn{6}{|l|}{ IDDM } \\
\hline $\begin{array}{l}\text { Crall } \\
1978^{69}\end{array}$ & Postmortem & IDDM & 9 & $\%$ of vessel length narrowed & $\begin{array}{l}47 \% \text { had }>50 \% \text { arterial length } \\
\text { narrowing compared with } 1 \% \text { control }\end{array}$ \\
\hline $\begin{array}{l}\text { Valsania } \\
1991^{53}\end{array}$ & CA & $\begin{array}{l}\text { IDDM; age and symptom matched } \\
\text { to non-diabetic controls undergoing } \\
\text { clinically indicated CA }\end{array}$ & 32 & $\begin{array}{l}\text { Number of vessels with significant } \\
\text { stenosis ( }>70 \% \text { considered significant) }\end{array}$ & More multivessel disease \\
\hline $\begin{array}{l}\text { Pajunen } \\
2000^{54}\end{array}$ & CA & $\begin{array}{l}\text { IDDM; patients undergoing CA } \\
\text { for suspected CAD individually } \\
\text { matched to controls for various } \\
\text { parameters }\end{array}$ & 64 & $\begin{array}{l}\text { QCA to measure } \% \text { of vessel } \\
\text { involved and most severe stenosis } \\
(\%) \text {; atheroma burden; Gensini score }\end{array}$ & $\begin{array}{l}\text { More severe extensive and distal } \\
\text { disease }\end{array}$ \\
\hline \multicolumn{6}{|l|}{ NIDDM } \\
\hline $\begin{array}{l}\text { Calton } \\
1995^{44}\end{array}$ & CA & NIDDM; individually matched & 75 & Coronary score & $\begin{array}{l}\text { Higher scores; three vessel disease } \\
\text { more common; no more diffuse } \\
\text { disease }\end{array}$ \\
\hline $\begin{array}{l}\text { Hamby } \\
1979^{41}\end{array}$ & CA & NIDDM and IGT & 100 & Coronary score & $\begin{array}{l}\text { Higher coronary scores and more } \\
\text { three vessel disease (difference seen } \\
\text { only in those with } \\
\text { hypertriglyceridaemia) }\end{array}$ \\
\hline $\begin{array}{l}\text { Natali } \\
2000^{35}\end{array}$ & CA & NIDDM & $\begin{array}{l}\text { Analysis of } \\
2253 \\
\text { consecutive } \\
\text { patients }\end{array}$ & Coronary score & $\begin{array}{l}\text { More three vessel disease; higher } \\
\text { coronary score; greater effect on } \\
\text { female diabetic patients }\end{array}$ \\
\hline $\begin{array}{l}\text { Pajunen } \\
1997^{48}\end{array}$ & CA & $\begin{array}{l}\text { NIDDM; clinically indicated } \\
\text { angiography; individually } \\
\text { matched }\end{array}$ & 57 & $\begin{array}{l}\text { QCA to measure } \% \text { of vessel } \\
\text { involved and most severe stenosis } \\
(\%) \text {; atheroma burden; Gensini score }\end{array}$ & No difference \\
\hline $\begin{array}{l}\text { Vigorita } \\
1980^{31}\end{array}$ & Postmortem & $\begin{array}{l}\text { "Adult onset" DM; individually } \\
\text { matched for age and sex }\end{array}$ & 185 & $\begin{array}{l}\text { Number of coronary vessels with } \\
\text { significant (stenosis }>75 \% \text { ) } \\
\text { reduction in luminal area }\end{array}$ & More multivessel disease \\
\hline $\begin{array}{l}\text { Waller } \\
1980^{36}\end{array}$ & Postmortem & Onset of DM after age 30 & 229 & $\begin{array}{l}\text { Number of coronary vessels with } \\
\text { significant (stenosis }>75 \% \text { ) reduction } \\
\text { in luminal area }\end{array}$ & $\begin{array}{l}\text { More LMS; no difference in } \\
\text { number of stenoses between groups }\end{array}$ \\
\hline $\begin{array}{l}\text { Thomas } \\
2002^{52}\end{array}$ & CA & $\begin{array}{l}\text { NIDDM; comparison with } 23 \\
\text { non-diabetic patients; unmatched }\end{array}$ & 59 & QCA & More severe and distal disease \\
\hline $\begin{array}{l}\text { Waldecker } \\
1999^{34}\end{array}$ & CA & $\begin{array}{l}\text { NIDDM presenting with acute MI; } \\
\text { compared with } 358 \text { controls }\end{array}$ & 46 & $\begin{array}{l}\text { Location and severity of culprit } \\
\text { lesion; number of diseased vessels }\end{array}$ & More multivessel disease \\
\hline \multicolumn{6}{|c|}{ IDDM and NIDDM } \\
\hline $\begin{array}{l}\text { Abadie } \\
1983^{49}\end{array}$ & CA & $\begin{array}{l}\text { All DM; patients with "severe } \\
\text { ischaemic heart disease" }\end{array}$ & 36 & Coronary score & $\begin{array}{l}\text { No difference in coronary score or } \\
\text { number of vessels involved }\end{array}$ \\
\hline $\begin{array}{l}\text { Cariou } \\
2000^{43}\end{array}$ & CA & $\begin{array}{l}\text { All DM; clinically indicated CA; } \\
\text { matched for age and sex }\end{array}$ & 50 & $\begin{array}{l}\text { Number of significant stenoses } \\
(>50 \%)\end{array}$ & $\begin{array}{l}\text { More significant stenoses; no } \\
\text { difference in number of vessels } \\
\text { involved or diffuse or distal disease; } \\
\text { more LMS disease }\end{array}$ \\
\hline $\begin{array}{l}\text { Dortimer } \\
1978^{32}\end{array}$ & CA & $\begin{array}{l}\text { All DM; individually matched } \\
\text { for age, sex, and high or low risk } \\
\text { factor status }\end{array}$ & 37 & Coronary score & $\begin{array}{l}\text { Increased coronary score; no more } \\
\text { diffuse disease. }\end{array}$ \\
\hline $\begin{array}{l}\text { Hochman } \\
1988^{50}\end{array}$ & Postmortem & $\begin{array}{l}\text { All DM; specimens examined } \\
\text { from patients with suspected CAD }\end{array}$ & 25 & $\begin{array}{l}\text { Number of significant stenoses } \\
(>75 \%)\end{array}$ & No difference \\
\hline $\begin{array}{l}\text { Melidonis } \\
1999^{33}\end{array}$ & CA & $\begin{array}{l}\text { All DM; patients with } \\
\text { angiographically determined CAD } \\
\text { were included and matched to } \\
\text { controls }\end{array}$ & 463 & $\begin{array}{l}\text { Number of diseased vessels; } \\
\text { location of disease; . luminal width }\end{array}$ & More three vessel disease; more RCA \\
\hline $\begin{array}{l}\text { Wilson } \\
1983^{47}\end{array}$ & CA & $\begin{array}{l}\text { All DM; matched to non-diabetic } \\
\text { controls }\end{array}$ & 58 & Number of major and minor lesions & $\begin{array}{l}\text { More major stenoses; more } \\
\text { intermediate segment disease }\end{array}$ \\
\hline
\end{tabular}

CA, coronary angiography; DM, diabetes mellitus; IDDM, insulin dependent diabetes mellitus; IGT, impaired glucose tolerance; LMS, left main stem; MI, myocardial infarction; NIDDM, non-insulin dependent diabetes mellitus; QCA, quantitative coronary angiography; RCA, right coronary artery.

obstruction. Moreover, diabetic CAD is more diffuse with a greater atheroma burden. Increasing severity of CAD in diabetic patients is associated with higher mortality. ${ }^{35}$ Given these data one can hypothesise that disease progression is an important factor in the poorer outcomes after PCI. Therefore, one would expect that any pharmacological interventions that reduce disease severity should translate to improved outcomes.

\section{FACTORS IMPLICATED IN MODULATING DIABETIC CAD SEVERITY}

Table 2 outlines factors implicated in modulating the severity of CAD.

\section{Sex}

Several studies reporting increased severity of disease noted that this was particularly notable in female diabetic patients. $^{3348}$ The authors hypothesised that there may be a loss of the cardioprotection seen in premenopausal women. Insulin has been shown to affect the secretion of sex steroids, although it remains unclear as to whether this is of significance. $^{56}$

\begin{tabular}{l} 
Table 2 Factors that modulate the severity of \\
CAD \\
\hline Sex \\
Ethnicity \\
Lipids \\
Insulin resistance \\
Inflammation \\
Hyperglycaemia \\
\hline
\end{tabular}




\section{Ethnicity}

In certain ethnic groups mortality rates from CAD are $40 \%$ higher than those seen among whites. ${ }^{5758}$ Two studies examined diabetic patients of Indian and Middle Eastern origin. They support the hypothesis of increased CAD but offer no definitive answer as to whether there is a different pattern. Calton and colleagues ${ }^{44}$ examined coronary angiograms of 75 Indian patients with NIDDM with a diagnosis of either stable or unstable angina. There was no significant difference in age or coronary risk factors between the two groups. Diabetic patients had higher coronary artery scores suggesting increased severity; however, there was no evidence of a more diffuse pattern of disease. They did more commonly have three vessel disease.

Thomas and colleagues ${ }^{52}$ examined 106 consecutive angiograms of Arab women undergoing cardiac catheterisation. They found that 82 angiograms showed evidence of CAD. Of these, 59 had NIDDM and had an increased severity of disease. There was also an increased incidence of mid and distal left anterior descending artery disease, as well as an increased number of long lesions and more distal disease. It should be noted, however, that this was a relatively small study and the patients were not individually matched.

A small study has shown no difference in CAD score between Asians and whites. ${ }^{59}$ More studies are required to determine the effect of ethnic variation on CAD severity.

\section{Lipids}

Kasaoka and colleagues ${ }^{45}$ examined the importance of lipid status and DM as independent risk factors for CAD severity and extent. They examined the coronary angiograms of 204 Japanese patients with previous myocardial infarction or angina who had angiographically proven CAD. Although both diabetes and hypercholesterolaemia were associated with more severe $\mathrm{CAD}$, they found that hypercholesterolaemia had a greater influence.

The severity of angiographic CAD is related to the number of triglyceride rich lipoprotein particles and plasma $\operatorname{Lp}(\mathrm{a})$ lipoprotein concentration in patients with NIDDM. ${ }^{60}$ In another study examining patients with NIDDM, angiographic disease severity was shown to be positively associated with intermediate density lipoprotein and negatively associated with a subtype of high density lipoprotein. ${ }^{61}$ Many of the studies in the past have not taken lipid profile into account and may have been subject to confounding.

\section{Insulin resistance}

A small Japanese study has shown a correlation between a biochemical correlate of insulin resistance and CAD severity in non-diabetic patients. ${ }^{62}$ It is unknown how insulin resistance affects disease severity in patients with NIDDM.

\section{Inflammation}

Increased serum $C$ reactive protein is associated with greater coronary risk and predicts the severity of carotid artery atherosclerosis. ${ }^{63}$ The relation between $\mathrm{C}$ reactive protein concentration and CAD severity remains unclear with two studies showing conflicting results. ${ }^{64}{ }^{65}$ Upregulation of endothelial adhesion molecules such as VCAM-l is implicated in atherogenesis. However, the association between CAD severity and soluble VCAM-1 concentration is unknown.

\section{Hyperglycaemia}

Increasing hyperglycaemia, as measured by the percentage of glycosylated haemoglobin Alc, is associated with increased severity of disease. Despite this the importance of glucose lowering interventions in reducing cardiovascular risk and its influence on outcome after PCI remains controversial.

The initial results from the UKPDS (UK prospective diabetes study) showed only minimal benefits from tight glycaemic control with respect to macrovascular disease. Each $1 \%$ reduction in haemoglobin Alc was associated with a $14 \%$ reduction in risk for myocardial infarction. ${ }^{66}{ }^{67}$ However, relatively few macrovascular events were recorded in this study limiting its power to detect a statistical reduction. Poor glycaemic control as measured by glycosylated haemoglobin Alc concentrations at the time of PCI has been shown to be an independent predictor of restenosis in patients with DM. ${ }^{68}$ The importance of tight glycaemic control after PCI needs further investigation but is likely to be associated with an improvement in outcome. BARI 2D (bypass angioplasty revascularisation investigation) will address this issue.

In addition to more familiar risk factors, diabetic CAD may also be modulated by a number of poorly understood parameters. More studies are required to determine the relation between insulin resistance, inflammation, and CAD severity. The association between lipid lowering treatment, plaque regression, and improvement in outcome is well known. Similarly, pharmacological modulation of inflammation and insulin resistance may reduce disease severity in these patients.

\section{CONCLUSIONS}

Hyperglycaemia and insulin resistance, the two mechanisms that define NIDDM, drive the atherosclerotic process. The majority of studies confirm that NIDDM is associated with more severe $\mathrm{CAD}$, which in turn is associated with a poorer prognosis.

Recent advances in our knowledge of the mechanisms underlying diabetes and atherosclerosis point to the shared importance of insulin resistance and inflammation in addition to hyperglycaemia in modulating disease severity. Reducing levels of insulin resistance and inflammation in addition to tight glycaemic control may be especially beneficial for the diabetic population undergoing PCI. The relation between these parameters requires clarification.

The pattern of diabetic CAD remains incompletely characterised. Most studies to date show a greater number of significant stenoses, more diffuse disease, and multivessel involvement. However, it is still unknown whether specific types of lesion and anatomical locations are affected more in the diabetic patients, accounting for their poorer prognosis.

Other characteristics of diabetic disease have already been elucidated such as the increase in calcified disease and decreased collateral vessel formation. These differences are implicated in the poorer prognosis after PCI. An understanding of the molecular mechanisms underlying these differences may lead to the development of pharmacological interventions to modulate them.

A more complete understanding of the anatomy of diabetic $\mathrm{CAD}$ and the factors that influence the pattern and severity can facilitate a more targeted approach to the development of new treatments designed to improve outcome in this growing patient population.

\section{Authors' affiliations \\ K P Morgan, A Kapur, K J Beatt, Imperial College, London, UK}

\section{REFERENCES}

1 George CJ, Baim DS, Brinker JA, et al. One-year follow-up of the stent restenosis (STRESS I) study. Am J Cardiol 1998;81:860-5.

2 Serruys PW, de Jaegere P, Kiemeneij F, et al. A comparison of balloonexpandable-stent implantation with balloon angioplasty in patients with 
coronary artery disease. Benestent Study Group. N Engl J Med 1994;331:489-95.

3 Van Belle E, Bauters C, Hubert E, et al. Restenosis rates in diabetic patients: a comparison of coronary stenting and balloon angioplasty in native coronary vessels. Circulation 1997:96:1454-60.

4 Bhatt DL, Marso SP, Lincoff AM, et al. Abciximab reduces mortality in diabetics following percutaneous coronary intervention. J Am Coll Cardiol 2000;35:922-8

5 Morice MC, Serruys PW, Sousa JE, et al. A randomized comparison of a sirolimus-eluting stent with a standard stent for coronary revascularization. N Engl J Med 2002;346:1773-80.

6 Moses JW, Leon MB, Popma JJ, et al. Sirolimus-eluting stents versus standard stents in patients with stenosis in a native coronary artery. N Engl J Med 2003:349:1315-23.

7 Serruys PW, Unger F, Sousa JE, et al. Comparison of coronary-artery bypass surgery and stenting for the treatment of multivessel disease. N Engl J Med 2001;344:1117-24

8 Anon. Comparison of coronary bypass surgery with angioplasty in patients with multivessel disease. The Bypass Angioplasty Revascularization Investigation (BARI) Investigators. N Engl J Med 1996;335:217-25.

9 Feit F, Brooks MM, Sopko G, et al. Long-term clinical outcome in the bypass angioplasty revascularization investigation registry: comparison with the randomized trial. BARI Investigators. Circulation 2000;101:2795-802.

10 Vergely P. De l'angine de poitrine dans ses rapports avec le diabete. Gaz hedb de ned (ser 2) 1883;20:364.

11 Naunyn B. Der Diabetes Mellitus, 2nd edn. Vienna: Holder, 1906:260.

12 Chaour M, Theroux P, Gilfix BM, et al. 'True' fasting serum insulin level, insulin resistance syndrome and coronary artery disease. Coron Artery Dis 1997;8:683-8

13 Abbasi F, Brown BW Jr, Lamendola C, et al. Relationship between obesity, insulin resistance, and coronary heart disease risk. J Am Coll Cardiol 2002;40:937-43.

14 Lempiainen P, Mykkanen L, Pyorala K, et al. Insulin resistance syndrome predicts coronary heart disease events in elderly nondiabetic men. Circulation 1999;100:123-8.

15 Anon. Tight blood pressure control and risk of macrovascular and microvascular complications in type 2 diabetes: UKPDS 38. UK Prospective Diabetes Study Group. BMJ 1998;317:703-13.

16 Aronson D, Rayfield EJ. How hyperglycemia promotes atherosclerosis: molecular mechanisms. Cardiovasc Diabetol 2002;1:1.

17 Ross R. Atherosclerosis: an inflammatory disease. N Engl J Med 1999:340:115-26.

18 King DE, Mainous AG III, Buchanan TA, et al. C-reactive protein and glycemic control in adults with diabetes. Diabetes Care 2003;26:1535-9.

19 Leinonen E, Hurt-Camejo E, Wiklund O, et al. Insulin resistance and adiposity correlate with acute-phase reaction and soluble cell adhesion molecules in type 2 diabetes. Atherosclerosis 2003; 166:387-94.

20 Mendall MA, Strachan DP, Butland BK, et al. C-reactive protein: relation to total mortality, cardiovascular mortality and cardiovascular risk factors in men. Eur Heart J 2000;21:1584-90.

21 Biasucci LM, Liuzzo G, Grillo RL, et al. Elevated levels of C-reactive protein at discharge in patients with unstable angina predict recurrent instability. Circulation 1999;99:855-60

22 Jager A, van Hinsbergh VW, Kostense PJ, et al. Increased levels of soluble vascular cell adhesion molecule 1 are associated with risk of cardiovascular mortality in type 2 diabetes: the Hoorn study. Diabetes 2000;49:485-91.

23 Moreno PR, Murcia AM, Palacios IF, et al. Coronary composition and macrophage infiltration in atherectomy specimens from patients with diabetes mellitus. Circulation 2000;102:2180-4.

24 Gyongyosi M, Yang P, Hassan A, et al. Coronary risk factors influence plaque morphology in patients with unstable angina. Coron Artery Dis 1999;10:211-9.

25 Marso SP, Giorgi LV, Johnson WL, et al. Diabetes mellitus is associated with a shift in the temporal risk profile of inhospital death after percutaneous coronary intervention: an analysis of 25,223 patients over 20 years. Am Heart J 2003;145:270-7.

26 Loutfi M, Mulvihill NT, Boccalatte $M$, et al. Impact of restenosis and disease progression on clinical outcome after multivessel stenting in diabetic patients. Cathet Cardiovasc Interv 2003:58:451-4.

27 Mosseri M, Nahir M, Rozenman Y, et al. Diffuse narrowing of coronary arteries in diabetic patients: the earliest phase of coronary artery disease. Cardiology 1998;89:103-10.

28 O'Connor NJ, Morton JR, Birkmeyer JD, et al. Effect of coronary artery diameter in patients undergoing coronary bypass surgery. Northern New England cardiovascular disease study group. Circulation 1996;93:652-5.

29 Cantor WJ, Miller JM, Hellkamp AS, et al. Role of target vessel size and body surface area on outcomes after percutaneous coronary interventions in women. Am Heart J 2002; 144:297-302.

30 Moise A, Theroux P, Taeymans Y, et al. Clinical and angiographic factors associated with progression of coronary artery disease. J Am Coll Cardiol 1984;3:659-67

31 Vigorita VJ, Moore GW, Hutchins GM. Absence of correlation between coronary arterial atherosclerosis and severity or duration of diabetes mellitus of adult onset. Am J Cardiol 1980;46:535-42

32 Dortimer AC, Shenoy PN, Shiroff RA, et al. Diffuse coronary artery disease in diabetic patients: fact or fiction? Circulation 1978;57:133-6

33 Melidonis A, Dimopoulos V, Lempidakis E, et al. Angiographic study of coronary artery disease in diabetic patients in comparison with nondiabetic patients. Angiology 1999;50:997-1006.

34 Waldecker B, Waas W, Haberbosch W, et al. Type 2 diabetes and acute myocardial infarction: angiographic findings and results of an invasive therapeutic approach in type 2 diabetic versus nondiabetic patients. Diabetes Care 1999;22:1832-8.

35 Natali A, Vichi S, Landi $P$, et al. Coronary atherosclerosis in type II diabetes: angiographic findings and clinical outcome. Diabetologia 2000:43:632-41.

36 Waller BF, Palumbo PJ, Lie JT, et al. Status of the coronary arteries at necropsy in diabetes mellitus with onset after age 30 years: analysis of 229 diabetic patients with and without clinical evidence of coronary heart disease and comparison to 183 control subjects. Am J Med 1980:69:498-506.

37 Abaci A, Oguzhan A, Kahraman S, et al. Effect of diabetes mellitus on formation of coronary collateral vessels. Circulation 1999;99:2239-42.

38 Arad $Y$, Newstein D, Cadet F, et al. Association of multiple risk factors and insulin resistance with increased prevalence of asymptomatic coronary artery disease by an electron-beam computed tomographic study. Arterioscler Thromb Vasc Biol 2001;21:2051-8.

39 Wong ND, Kouwabunpat D, Vo AN, et al. Coronary calcium and atherosclerosis by ultrafast computed tomography in asymptomatic men and women: relation to age and risk factors. Am Heart $J$ 1994; 127:422-30

40 Alderman EL, Corley SD, Fisher LD, et al. Five-year angiographic follow-up of factors associated with progression of coronary artery disease in the coronary artery surgery study (CASS). CASS participating investigators and staff. J Am Coll Cardiol 1993:22:1141-54.

41 Hamby RI, Sherman L. Duration and treatment of diabetes: relationship to severity of coronary artery disease. N Y State J Med 1979;79:1683-8.

42 Goraya TY, Leibson CL, Palumbo PJ, et al. Coronary atherosclerosis in diabetes mellitus: a population-based autopsy study. J Am Coll Cardiol 2002;40:946-53

43 Cariou B, Bonnevie L, Mayaudon H, et al. Angiographic characteristics of coronary artery disease in diabetic patients compared with matched nondiabetic subjects. Diabetes Nutr Metab 2000;13:134-41.

44 Calton R, Calton R, Dhanoa J, et al. Angiographic severity and morphological spectrum of coronary artery disease in non insulin dependent diabetes mellitus. Indian Heart J 1995;47:343-8.

45 Kasaoka S, Okuda F, Satoh A, et al. Effect of coronary risk factors on coronary angiographic morphology in patients with ischemic heart disease. Jpn Circ J 1997;61:390-5.

46 Ledru F, Theroux P, Lesperance J, et al. Geometric features of coronary artery lesions favoring acute occlusion and myocardial infarction: a quantitative angiographic study. J Am Coll Cardiol 1999;33:1353-61.

47 Wilson CS, Gau GT, Fulton RE, et al. Coronary artery disease in diabetic and nondiabetic patients: a clinical and angiographic comparison. Clin Cardiol 1983;6:440-6

48 Pajunen P, Nieminen MS, Taskinen MR, et al. Quantitative comparison of angiographic characteristics of coronary artery disease in patients with noninsulin-dependent diabetes mellitus compared with matched nondiabetic control subjects. Am J Cardiol 1997;80:550-6.

49 Abadie E, Masquet C, Guiomard A, et al. Coronary angiography in diabetic and non-diabetic patients with severe ischaemic heart disease. Diabetes Metab 1983;9:53-7.

50 Hochman JS, Phillips WJ, Ruggieri D, et al. The distribution of atherosclerotic lesions in the coronary arterial tree: relation to cardiac risk factors. Am Heart J 1988;116:1217-22.

51 Reiber JH, Goedhart B, Brand GJ, et al. Quantitative coronary arteriography: current status and future. Heart Vessels 1997;(suppl 12):209-11.

52 Thomas CS, Cherian G, Hayat NJ, et al. Angiographic comparison of coronary artery disease in Arab women with and without type II diabetes mellitus. Med Princ Pract 2002;11(suppl 2):63-8.

53 Valsania P, Zarich SW, Kowalchuk GJ, et al. Severity of coronary artery disease in young patients with insulin-dependent diabetes mellitus. Am Heart J 1991;122:695-700.

54 Pajunen P, Taskinen MR, Nieminen MS, et al. Angiographic severity and extent of coronary artery disease in patients with type 1 diabetes mellitus. Am J Cardiol 2000;86:1080-5.

55 Fuster V, Stein B, Ambrose JA, et al. Atherosclerotic plaque rupture and thrombosis: evolving concepts. Circulation 1990;82:||47-59.

56 Maturana MA, Spritzer PM. Association between hyperinsulinemia and endogenous androgen levels in peri- and postmenopausal women. Metabolism 2002;51:238-43.

57 McKeigue PM, Miller GJ, Marmot MG. Coronary heart disease in south Asians overseas: a review. J Clin Epidemiol 1989;42:597-609.

58 Balarajan R. Ethnic differences in mortality from ischaemic heart disease and cerebrovascular disease in England and Wales. BMJ 1991;302:560-4.

59 Dhawan J, Bray CL. Angiographic comparison of coronary artery disease between Asians and Caucasians. Postgrad Med J 1994;70:625-30.

60 Tkac I, Kimball BP, Lewis G, et al. The severity of coronary atherosclerosis in type 2 diabetes mellitus is related to the number of circulating triglyceride-rich lipoprotein particles. Arterioscler Thromb Vasc Biol 1997;17:3633-8.

61 Syvanne M, Taskinen MR. Lipids and lipoproteins as coronary risk factors in non-insulin-dependent diabetes mellitus. Lancet 1997;350(suppl 1):SI20-3.

62 Takezako T, Saku K, Zhang B, et al. Insulin resistance and angiographical characteristics of coronary atherosclerosis. Jpn Circ J 1999;63:666-73.

63 Blackburn R, Giral P, Bruckert E, et al. Elevated C-reactive protein constitutes an independent predictor of advanced carotid plaques in dyslipidemic subjects. Arterioscler Thromb Vasc Biol 2001;21:1962-8.

64 Hoffmeister A, Rothenbacher D, Bazner U, et al. Role of novel markers of inflammation in patients with stable coronary heart disease. Am J Cardiol 2001;87:262-6.

65 Mori T, Sasaki J, Kawaguchi $H$, et al. Serum glycoproteins and severity of coronary atherosclerosis. Am Heart J 1995;129:234-8. 
66 Anon. Intensive blood-glucose control with sulphonylureas or insulin compared with conventional treatment and risk of complications in patients with type 2 diabetes (UKPDS 33). UK prospective diabetes study (UKPDS) group. Lancet 1998;352:837-53.

67 Stratton IM, Adler Al, Neil HA et al. Association of glycaemia with macrovascular and microvascular complications of type 2 diabetes (UKPDS 35): prospective observational study. BMJ 2000;321:405-12.
68 Mazeika P, Prasad N, Bui S, et al. Predictors of angiographic restenosis after coronary intervention in patients with diabetes mellitus. Am Heart $J$ 2003; 145:1013-21

69 Crall FV Jr, Roberts WC. The extramural and intramural coronary arteries in juvenile diabetes mellitus: analysis of nine necropsy patients aged 19 to 38 years with onset of diabetes before age 15 years. Am J Med $1978 ; 64: 221-30$.

\section{IMAGES IN CARDIOLOGY}

\section{Spontaneous polymorphic ventricular tachycardia recorded during an electroencephalogram in a patient with apparent epilepsy}

A 60 year old woman presented to the emergency department after four episodes of seizure. She had already experienced two repeated episodes during the past year before admission. The physical examination, including a complete neurological examination, was normal. Despite an intravenous infusion of clonazepam, another episode of seizure occurred with unresponsiveness and tonicclonic movements followed by post-ictal confusion. The computed tomography of the head was normal. An electroencephalogram was then performed. During this recording, another episode of seizure occurred. As shown in the panel below, a polymorphic ventricular tachycardia (VT) started before any change of the electroencephalogram. The electrocerebral activity then showed an increasing amplitude followed at 14 seconds by a flattening and slowing activity (below). The polymorphic VT spontaneously resumed after 56 seconds (right panel). A long QT syndrome was diagnosed. $\beta$ Blocker treatment was started and a defibrillator implanted.

This recording demonstrates that a proven seizure can be related to a spontaneous polymorphic VT. This reinforces the idea that cardiac issues should be systematically considered in patients with a diagnosis of epilepsy remaining uncertain.

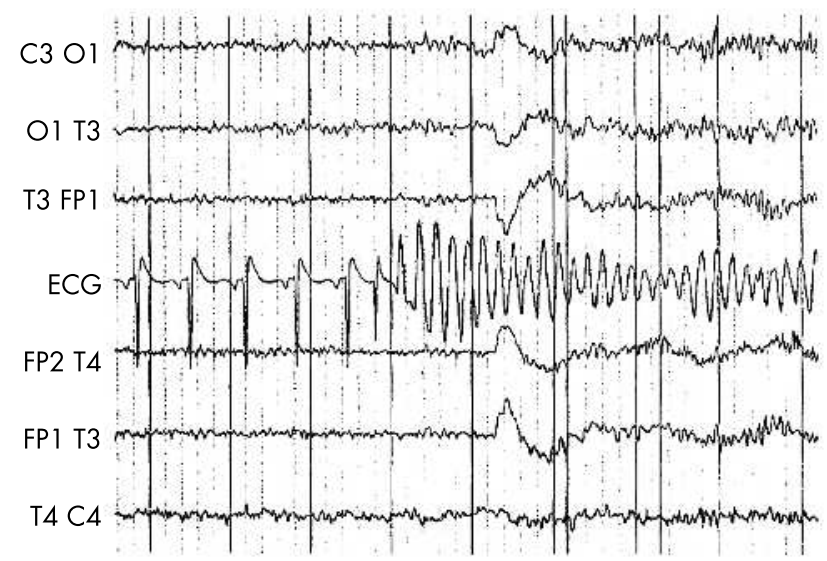

0
O Paziaud

O Piot

N Elbaz

olivier.paziaud@libertysurf.fr

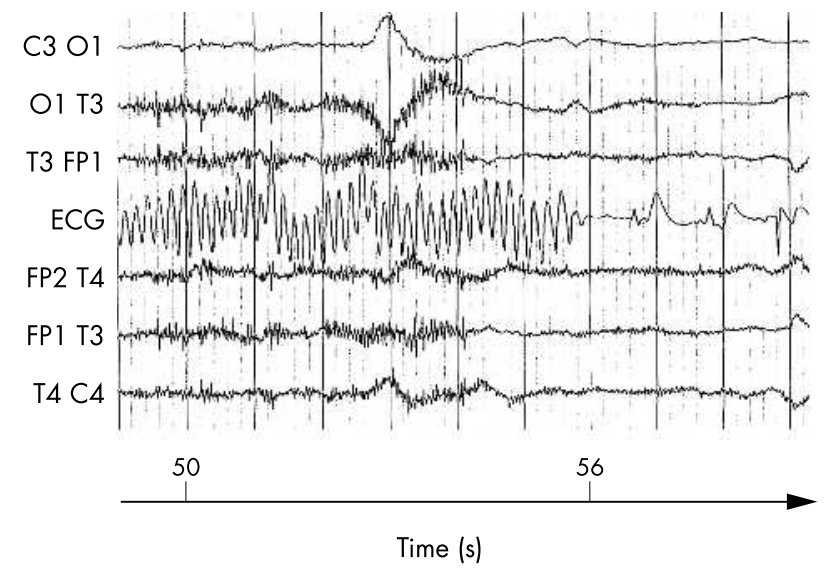

Spontaneous reduction of polymorphic VT after 56 seconds.

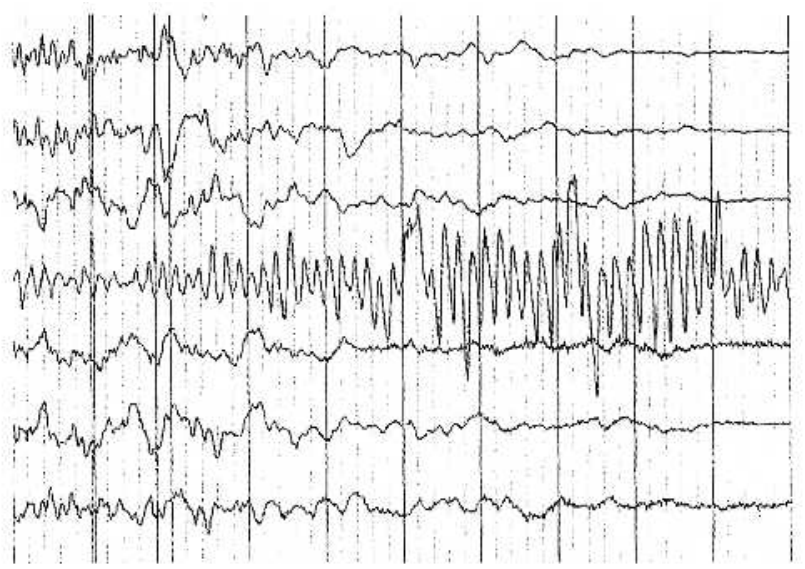

15

20

Time (s)

Occurrence of a spontaneous polymorphic VT during the recording of the electroencephalogram. Note that for better clarity, only six derivations of EEG are displayed, as changes in amplitude and activity were similar in 16 . 